\title{
青函トンネル海底部の地質
}

一断層と湧水——

北川修三*. 前田憲一**

\section{The Geological Outline of the Undersea Portion of the Seikan Tunnel}

\author{
Shuzo KITAGAWA and Kenichi MAEDA
}

\begin{abstract}
There are many faults in area of Kunnui Formation, but few in Kuromatsunai Formation.

It seems to the reason of the geological age and of which Kunnui Formation is mainly underlain by solid character's rock (tuff, lapilli tuff, and tuff breccia) and Kuromatsunai Formation is fluid quality (mudstone).

The biggest fault is F. 10 fault which appeared in about $33 \mathrm{~km}$. The thrust length seems to about five hundred meters, because Fukuyama Formation is in fault contact with Kunnui Formation (Kn 4).

About one kilometer of Kunnui Formation (tuff and mudstone, $\mathrm{Kn} 2 \sim \mathrm{Kn} 4$ ) near the fault is squeezing ground, and the maximum earth pressure amount to $2.0 \mathrm{MPa}$.

Excavating of main tunnel carried out by the circular short bench (with spring line drift) method after elavolate grouting.

On the other hand, during the construction there were four accidents of water inrushing in the area of fault zone.

Every restoration work took about five to twelve months.

In the fault zone, as advance boring came to deadlock, investigation for proving was carried out by short drilling (coring and noncoring) from working face and side well.

To prevent water inrushing, new technologies of measuring must be developed to grasp the process of seepaging and loosening of the ground. This is very important task for maintenance of tunnel.

Meanwhile, chemical quality of seepage water is almost near that of sea water and is alteration sea-water type by exchange of ion, and partially is hot-spring type.
\end{abstract}

\section{1.はじめに}

海底部のトンネル掘削では, 特に断覻の位置, 破砕帯 の規模揖よび滞水状況を早期に把握し，綿密な止水注入 並びに掘削の計画をたてることが最も重要である。青函 トンネルでは海上からの調査による海底地質図（縮尺 2 万分の 1) を参考にして, 坑道の地質調查結果（先進導 坑，作業坑では縮尺 $1 / 200$, 本坑では縮尺 $1 / 1000$ の地 質図を作成）和よび先進ボーリングから得られる情報に 基き，切羽先方予想図（縮尺 1/1000 で数百メートル間 の地質並びに湧水状況を記載したもの）を作成して工事 のための基礎資料としたが，断層破砕带およびその周辺

\footnotetext{
*日本鉄道建設公団本社

** 日本鉄道建設公団青函建設局
}

の影響帯では先進ボーリングが難航し，切羽からのコア

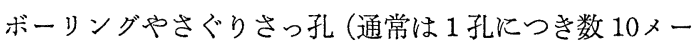
トル）により前方探査を行なわざるをえず，破砕帯の規 模や滞水状況を十分に調査出来ないことがあった。また 一方，止水注入後のさぐりさっ孔（チェック孔）でも止 水注入の効果を十分に把握出来なかったことがあり，い ずれも断層破破帯の部分で 4 回の異常出水事故を経験し ている。

本稿では主として, 異常出水の原因となった断層の性 状と海底部の湧水の水質 (化学分析結果) についてその 概要を述べる。

な拉，本稿は応用地質 24 巻第 3 号の「青函トンネル 海底部の地質 (その 1 ) 一一地質調查方法々地質の概要 一」, 24 巻 第 4 号の「青函トンネル海底部の地質（そ 
の 2)一一層位と不整合一」に続くものであり，地質 層序表（その 1 ，表 4 ）等を参照していただきたい。

\section{2. 断層について}

\section{1 津軽海峡西口付近の断層の分布状況}

津軽海陕西口付近一帯の地質図（図-1）によれば新第 三紀訓縫層より下位の地層分布域で断層が多く，それよ り上位の八雲層や黒松内層の分布域では極めて少ない。 これは主として岩質に起因するものと考光られ，最も広 く分布している訓縫層と黒松内層を比べてみると, 訓縫 層は, 泥岩部分もあるが火山磁凝灰岩や凝灰角砅岩を主 体とする碩を含む脆性の硬質岩で構成されているため, 地殼変動を受けた際に断層を生じやすく，一方泳ぼ均等 の細粒子からなる軟質泥岩を主体とする黒松内層は訓縫 層に比べて脆性度が低いため断層の少ない褶曲構造を生 じやすいものと考兄られる。坑道の掘削結果を見ても黒 松内層の部分ではトンネル料程 $29.4 \mathrm{~km}$ の向斜軸付近 で最大落差 $15 \mathrm{~m}$ の断層が認められたが，断層の数は少 なく大半は落差 $0.5 \mathrm{~m}$ 以下の面なし断層であり, 訓縫 層の部分では落差数 10 メートルから数百メートルに達 するものが数多く認められた。また，訓縫層の中の断層 では, 断層面に沿って玄武岩等の岩脈が貫入しているこ とが多く, 破砕帯や変質粘土帯が生じている。

最も落差が大きく，破破帯の広い断層は，トンネル粁 程 $33 \mathrm{~km}$ 付近に出現した F. 10 (F.は Fault の略で, 海上からの調査の段階で名付けられた断層名）で訓縫層 とその下位の福山層（トンネルルート付近では新第三紀 層の最下位層で, 本地域の基盤岩で㐫る古生層の上に不 整合でのっている）が断層面で接して和り落差数百メ一 トルに達するもの之推定される。福山層は熔結凝灰岩や 安山岩質凝灰岩などの硬質岩からなりこれが硬質で脆 性の古生層（陸上部では主として片理の発達した粘板岩 からなり，海上弾性波探查の結果では，P 波速度約 5.0 $\mathrm{km} / \mathrm{sec}$ ) に接しているため地殼変動の影響が，大きな落 差の断層となって表われたものと推定される。

\section{2 断層の性状}

2.2 .1 竜飛斜坑 $1222.80 \mathrm{~m}$ 付近 (水深 $25 \mathrm{~m}$, 土被 り $215 \mathrm{~m})$ の出水断層

（1）地質および調査の概要

最初の異常出水地点の断層であり, 図-2 亿示すよう に, ガラス質安山岩と凝死岩層（凝灰質シルト岩及びそ の上位の砂質凝灰岩）の間に坑道に斜交して玄武岩と安 山岩の岩脈が貫入している地帯で, 貫入する以前は断層 であったと推定される。このらち玄武岩の部分に断層す べり面 $\left(\mathrm{N} 18^{\circ} \mathrm{W} 65^{\circ} \mathrm{NE}\right)$ 特よび角䃯状の粘土化した部
分がある。これらの地層は, 陸上部の竜飛安山岩類の一 部であり, 北海道側の訓縫層の最下位の Kn 1 亿対比さ れている。

図は, 断層突破後の坑道状況を示して和り, 異常出水 の発生した時点 (切羽位置 $1222.80 \mathrm{~m}$ ) では, 注入横坑 の $\mathrm{G}_{2}$ は掘削されていない。出水以前には, 先進ボーリ ングの TB 3 号孔が実施されて拉り, 出水切羽付近で は, 坑道の右側壁から右へ $10 \mathrm{~m}$ 離れて天盤の上方 20 $\mathrm{m}$ の位置にあり，断面図には描かれていない。また， 切羽からのコアボーリング B 41, B 42-1, B 4 横坑から の B 42-2 が実施されている。TB 3 号孔では深度 362 $365 \mathrm{~m}$ まで玄武岩の破确带, そ机以深は, 砂質凝灰岩と なって抒り(いずれる図の右側で範囲外)，多量の涌水 があったため, セメンテーションで多大の時間を要し， ボーリング自体が難航した。(ワイヤライン式のコアボ ーリングで掘進長 $521 \mathrm{~m}$ で 11 箇月を要した）一方，切 羽ボーリング B 41，B 42-1 は破碎带と推定される部分 で掘進不能となっているが，涌水は無かった。

以上により，この付近の玄武岩岩脈の走向が注心゙南北 方向で，坑道と斜交する傾向が認められていたことすあ って，先進ボーリングは右側 1 本だけであるが, 1217.00 $\mathrm{m}$ の切羽前方に多量の地下水を胚胎した安山岩と玄武 岩の破砕帯があることが推定され, 切羽止水注入が実施 された。〔注入時の 1 孔当り最大湧水量 $1000 \mathrm{l} / \mathrm{min}$ ，最 大涌水圧力 $25 \mathrm{kgf} / \mathrm{cm}^{2}$, 注入孔数 36 孔, 薬液注入量 (LW) $259 \mathrm{~m}^{3}$ ，セメント注入量 $28 \mathrm{~m}^{3}$ ]

\section{(2) 異常出水状況}

昭和 44 年 2 月 13 日， $1222.80 \mathrm{~m}$ 亿達した際，切羽の 左下に変質した軟弱な安山岩が出現し, 約 $50 l / \mathrm{min}$ の 涌水があった。 $125 \mathrm{H}$ 型支保工を $1.3 \mathrm{~m}$ 間隔で建込み， 矢板で左側壁を縫地し, 切羽にも約 $2 \mathrm{~m}^{2}$ の鏡押えを行 なった。

2 月 14 日，右側の堅固な安山岩に発破をかけ，ずり を2台 (約 $5.4 \mathrm{~m}^{3}$ ). 取った時, 4 時 30 分頃より切羽の 左側約 $1 / 3$ が坑口側に押し出される（崩壊量約 $10 \mathrm{~m}^{3}$ ) と共に涌水が $1 \mathrm{~m}^{3} / \mathrm{min}$ に増加し，125H 型支保工 6 基 の左側壁側が坑口方向に凸に変形した。涌水は，左側壁 に出現した黒色ガラス質安山岩と玄武岩脈（部分的に粘 土化している）の境目（吵間）から顕著に認められ，間 歇泉のように放出と停止をくり返しながら次第にその量 が増加した。間隙水圧が上昇して割目に詰った粘土が流 された時濁水となり，これが次第に澄んだ水となって流 出した後湧水が一時止り, 再び濁水が流出するものと考 光られる。2月 15 日 6 時 50 分, 左側からの反流出して いた湧水は急にその量が増加すると共に，アーチ部から 

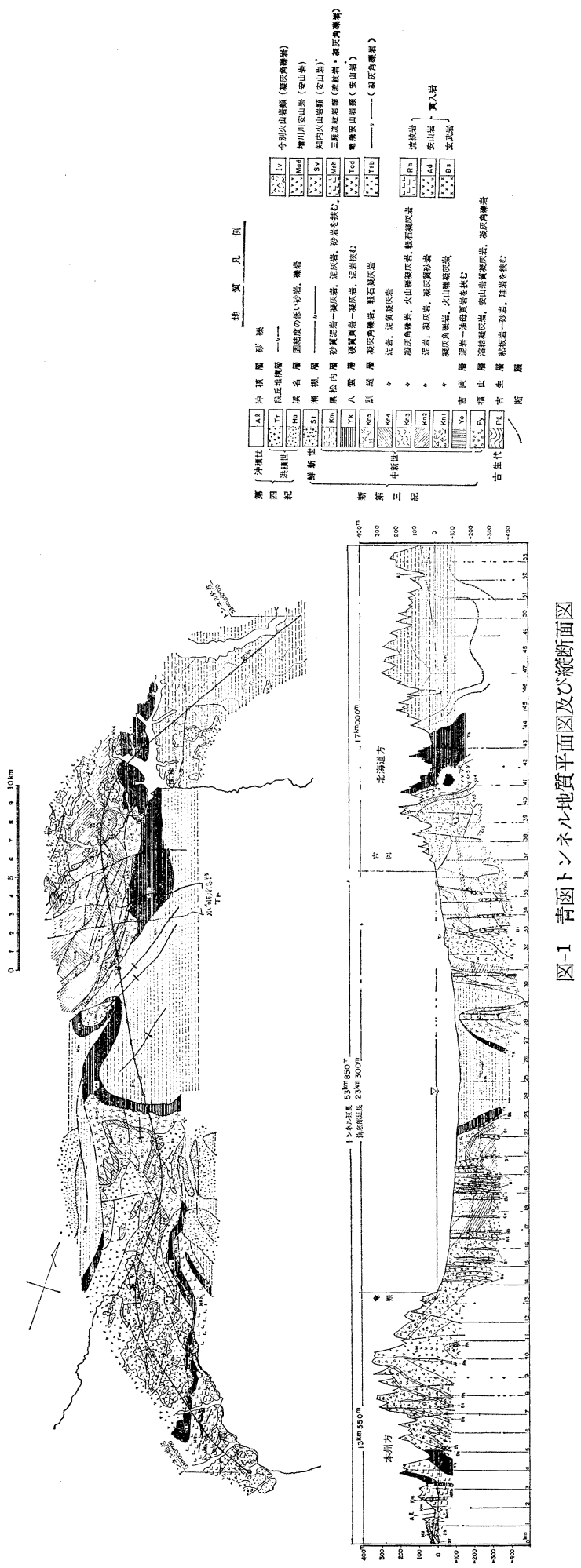


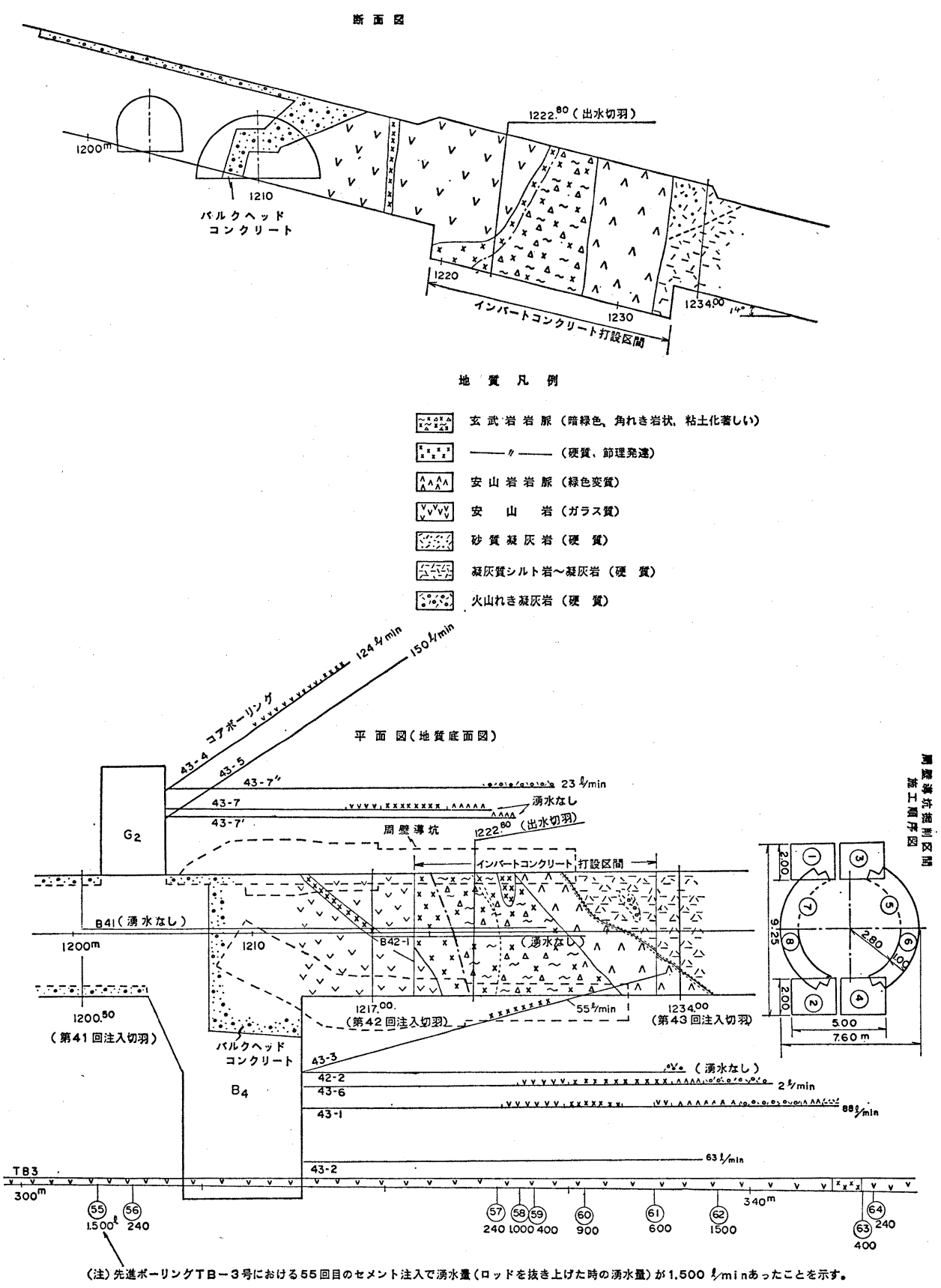

図-2 竜飛斜坑 $1220 \mathrm{~m}$ 付近地質平面図及び維断面図

も濁水が流出し，土砂は切羽から支保工 4 基目まで押し 出された。この時点で涌水量は約 $4 \mathrm{~m}^{3} / \mathrm{min}$ であった。 その後約 10 時間後, 最高の $11 \mathrm{~m}^{3} / \mathrm{min}$ となり, 以後次 第に減水し， 2 日後約 $5 \mathrm{~m}^{3} / \mathrm{min}$ 飞落着いた。な和湧水 の水質は海水に極めて近いものであることが化学分析の
結果判明した。〔水没区間長 $151 \mathrm{~m}$ ，流出土砂埋没区間 $15 \mathrm{~m}$ (土砂量約 $300 \mathrm{~m}^{3}$ )]

（3）復旧工事の概要と掘削後の観察

バルクヘッドコンクリート構築後, $\mathrm{G}_{2}$ 横坑を掘削し, 図に示すように $\mathrm{G}_{2}, \mathrm{~B}_{4}$ の両横坑からコアボーリング 
43-1 から 43-7" までを実施して玄武岩や安山岩の岩脈 の走向等を把握した後, 復旧のための止水注入が実施さ れた。〔注入時の 1 孔当り最大湧水量 $1500 \mathrm{l} / \mathrm{min}$, 最大 湧水圧力 $25 \mathrm{kgf} / \mathrm{cm}^{2}$, 注入孔数 241 孔, セメント注入 量 $2118 \mathrm{~m}^{3}$, LW 注入量 $348 \mathrm{~m}^{3}$, その他薬液注入量 $82 \mathrm{~m}^{3}$ ]

掘削は周壁導坑先進上半先進工法 (図の施工順序参照) によって行われた。メッセル工法により周壁導坑を掘削 し，コンクリートにより埋戻し後，上半，下半及びイン バート部分を施工している1)。インバートコンクリート 打設部分の底盤の観察で, セメントグラウト脈は玄武岩 の角礫状部に最大幅 $30 \mathrm{~cm}$ のものが 1 条認められ，ま た角礫状部の一部から $80 \mathrm{l} / \mathrm{min}$ の湧水があった。安山 岩岩脈と凝灰岩層の境界には $3 \mathrm{~cm} \sim 8 \mathrm{~cm}$ 幅のセメント グラウト脈が連続して入って括り，境界付近は変色して いるが堅固である。

（4）異常出水の原因について

断層破砕帯付近に多くの水道があり，グラウトで一時 充填されていた部分が掘削に伴ら緩みにより開口し，水 圧によって脆弱な部分が破壊されたためと考えられる。

$2.2 .233 \mathrm{~km}$ 付近 F. 10 断層 (本坑 $33.0 \mathrm{~km}$ 地点で 水深 $60 \mathrm{~m}$, 土被り $119 \mathrm{~m})$

(1) 地質拉よび調查の概要

F. 10 および出水断層（昭和 49 年 1 月 8 日, 北海道側 の作業坑 $3509.60 \mathrm{~m}$ で異常出水のあったところで次項 で述べる）が図-3に記載されている。

F. 10 は走向がほ心゙南北で，傾斜の変化の激しい逆断 層 $(32 \mathrm{k} 950 \mathrm{~m}$ 付近で他の断層で切られて不連続となっ て抒り, 作業坑では $\mathrm{NS} 65^{\circ} \sim 70^{\circ} \mathrm{E}$, 本坑では $\mathrm{N} 5^{\circ} \mathrm{W}$ $\left.90^{\circ}\right)$ で，作業坑で訓縫層（Kn 4 の褐色泥岩）とそれよ り下位の福山層（安山岩質凝灰岩）が接していることか ら落差は数百メートルに達するものと推定される。

この断層の影響を受けているためと考えられるが，周 辺一帯は, 膨張性地山となって拉り, 先進導坑および作 業坑の先進ボーリング(ワイヤライン式コアボーリング) がモンモリロナイトを多含する泥岩や凝灰岩の分布域で 難航し, 工法の変更を余儀なくされた。作業坑では $3 \mathrm{k}$ $041 \mathrm{~m}$ から開始の SB-9 号孔は $223 \mathrm{~m}$ で掘進不能とな

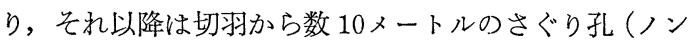
コア）やコアボーリングによって前方探査を行ないなが ら掘進している。その後ボーリングの試験を重ねて二重 管リバース工法 ${ }^{10)}$ が開発され，作業坑から本坑調查のた めのコアボーリング $\mathrm{MB} 1$ ～MB 8，和よび (1)〜 (11) が実 施され，F.10 执よび出水断層が探査された。 本坑の地質は大別すると, (1) $33 \mathrm{k} 200 \mathrm{~m} \sim 33 \mathrm{k} 500 \mathrm{~m}$ 間
は軟質の凝死岩〜泥質凝灰岩之や〉硬質の褐色泥岩の互 層部分で断層が多い。(時代は Kn 2 に属する) (1) $33 \mathrm{k}$ $000 \mathrm{~m} \sim 33 \mathrm{k} 200 \mathrm{~m}$ 間は F. 10 の破砕帯に沿った最も軟 弱な地带（粗粒凝灰岩一C. Tf-の一軸圧縮強度は $30 \mathrm{kgf} / \mathrm{cm}^{2}$ 前後) で Kn 3 に属する。 $32 \mathrm{k} 800 \mathrm{~m}$ $33 \mathrm{k} 000 \mathrm{~m}$ 間は，F.10 破砕帯を含み，貫入岩の玄武岩 及び福山層の安山岩質凝灰岩の分布域で地下水を泼胎し ている。 $\ominus 32 \mathrm{k} 760 \mathrm{~m} \sim 32 \mathrm{k} 800 \mathrm{~m}$ 間は出水断層破砕帯 となる7。

本坑の地質は，上記ボーリングの他，図に示すように 作業坑側壁 (本坑側) の弾性波探查結果（受振点間隔 3 $\mathrm{m}$ 及び $5 \mathrm{~m}$ ) からも予測されて拉り, 次に述べる土圧 測定結果と共に本坑掘削のための資料となっている6

(2) 土王測定について

上記 F. 10 に沿った Kn 2 㘧よび Kn 3 の分布域で, まず，作業坑，先進導坑でストレインゲージ，カールソ ン型ひずみ計和よびロードセルにより土圧を測定し，そ の結果に基いて本坑での土圧を推定して岩盤分類を行な っている。

土圧測定について概要を述べると，最大土圧は先進導 坑で 200 tonf $/ \mathrm{m}^{2}$, 作業坑で 150 tonf $/ \mathrm{m}^{2}$ 程度であり, この付近では，一般に掘削後約 20 日間で平衡に達して 特り，20日目の土圧を $100 \%$ とすれば，2 日目で $50 \%$ ， 5 日目で $75 \% ， 10$ 日目で $90 \%$ と大きい土圧が非常に 早く発生している。

本坑では，後に述べる周壁導坑および上半部で測定し ているが，ほ心゙想定通り最大值は 200 tonf $/ \mathrm{m}^{2}$ に達して いる。また，鉛直土圧は，水平土圧より一般に $30 \sim 40$ tonf $/ \mathrm{m}^{2}$ 多( ${ }^{3)}$ 。

(3) 掘削結果について

F. 10 に接近した Kn 3 の分布域で，作業坑，本坑共 に掘削が難航し（作業坑では湧水がなかったので止水注 入を行わずに F.10を突破しているが，本坑では入念な 注入が行われた)，図に示すようにとれぞれ縫い返しを 行なっている。特に本坑では $33 \mathrm{k} 200 \mathrm{~m}$ 付近で強大な 土圧のために鋼管支保工の沈下ならびに座屈が著しく， 上半部分をコンクリートで埋戻しを余儀なくされ，それ 以後スプリングラインの位置に周壁導坑を先進させてコ ンクリートで中埋め後, 円形ショートベンチ工法で掘削 するスプリングサイロット工法が採用されている。作業 坑でのロードヘッダーによるショートベンチ工法に対し て本坑でのスプリングサイロット工法といらそれぞれ不 良地質に詨処した工法が F.10 の方向に沿って採用され ていることから岩盤状態を対比することが出来る。

弾性波探查結果では, 動的ポアソン比 $0.38 \sim 0.43$, 


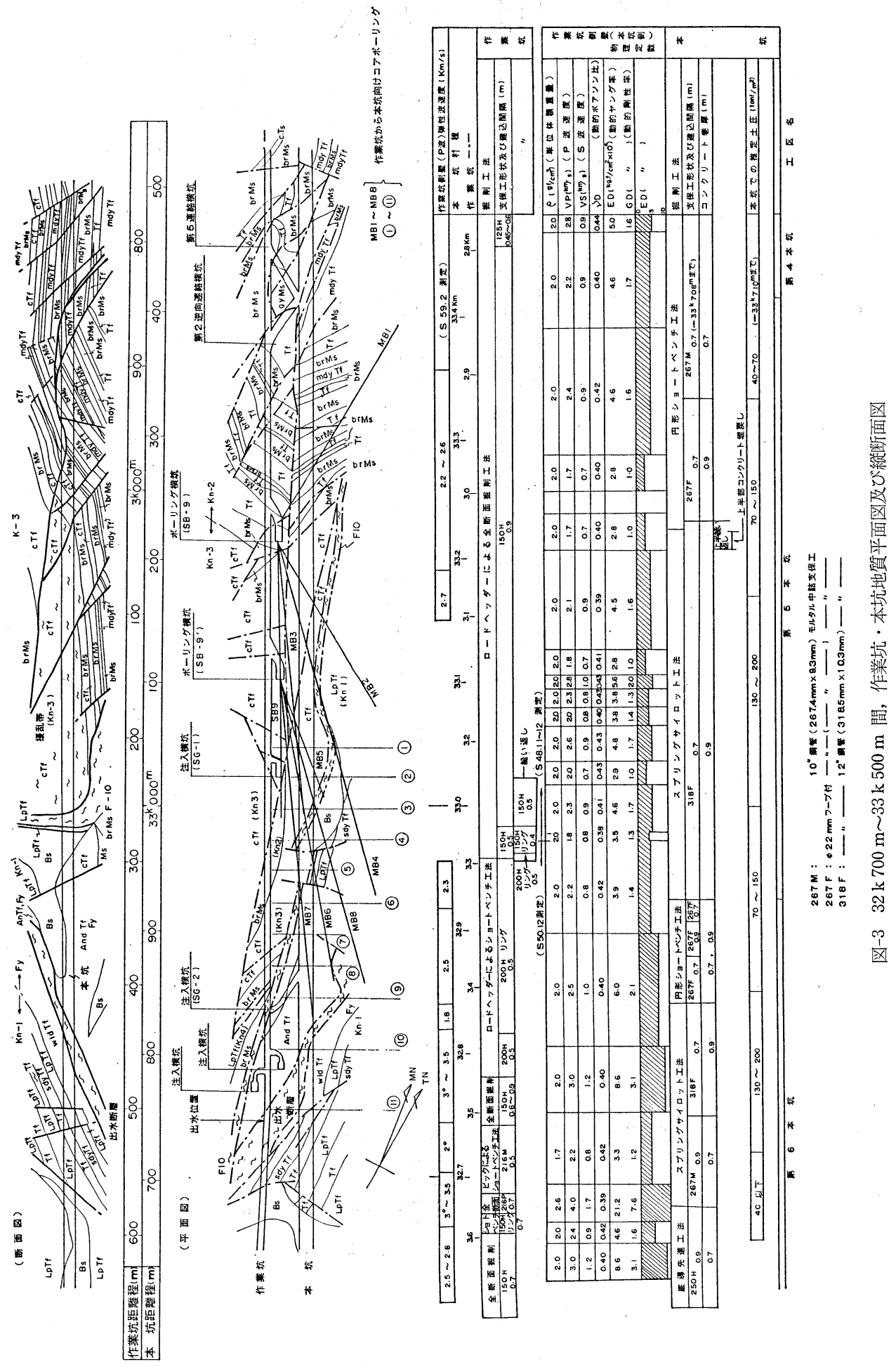




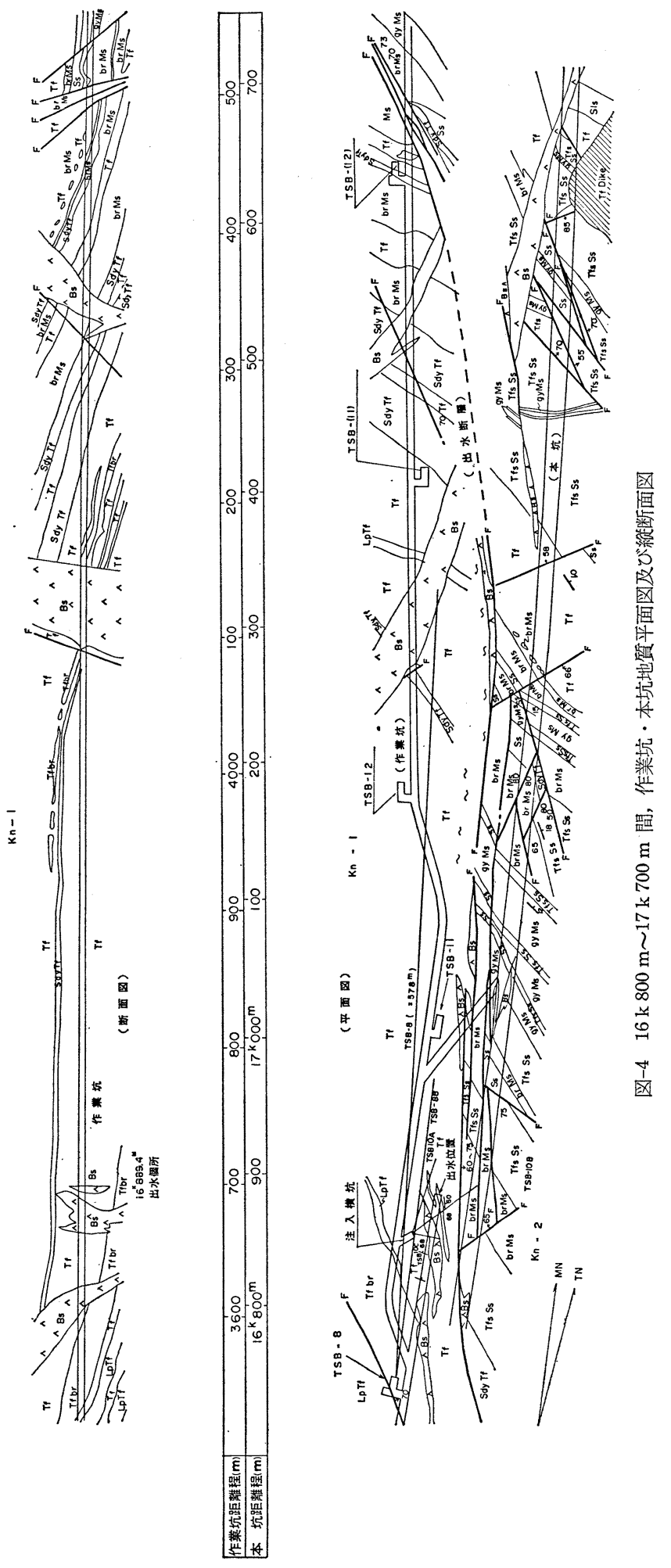




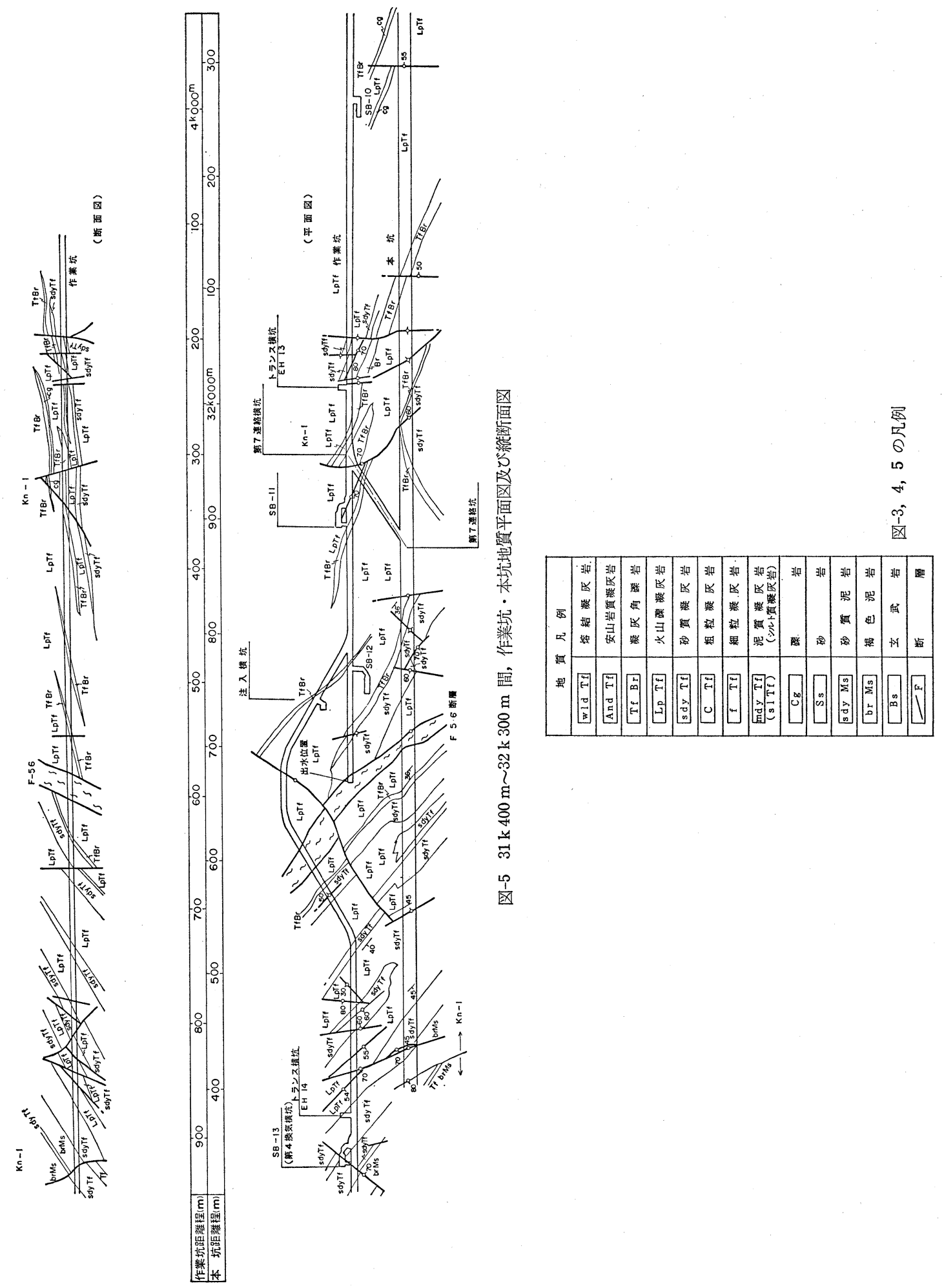


動的ヤング率 $2.8 \sim 6.0 \times 10^{4} \mathrm{kgf} / \mathrm{cm}^{2}$ の值を示してお り，岩盤としての性状は相当不良な状態である6)。

2.2 .3 吉岡作業坑 $3509.60 \mathrm{~m}$ (本坑換算 $32 \mathrm{k} 746.85$ $\mathrm{m}$ ) 付近 (水深 $58 \mathrm{~m}$, 土被り $134 \mathrm{~m}$ ) 出水断層 (1) 地質及び調査の概要（図-3 参照）

前項の F. 10 に近接する部分で, 作業坑が F. 10 を通 過して堅硬な福山層の安山岩質凝灰岩に入ったため, $3470 \mathrm{~m}$ からショートベンチ工法から発破による全断面 掘削工法に変更して掘削が行われた。 $3502 \mathrm{~m}$ で断層に 遭遇して破砕帯に入り，3509.60 m に達した時点で, 変 状著しいため縫い返しを行なっている。

先進ボーリングが行われていないため, 切羽からさぐ りさっ孔により前方を探査しているが，破砕帯は探知さ れていない。

湧水については，この切羽の近傍でさぐり孔により 2 度探知されている。1 度目は切羽 $3445 \mathrm{~m}$ から左上方 16 $\mathrm{m}$ 地点で, $1000 \mathrm{l} / \mathrm{min}$ の涌水があったが 3 日後 $44 \mathrm{l} / \mathrm{min}$ に減少した。水質分析の結果は, 塩分濃度が低い（総イ オン量が海水の約 1/3）ものであった。

2 度目は, 切羽 $3467 \mathrm{~m}$ から $50 \mathrm{~m}$ 地点で $360 l / \mathrm{min}$ の湧水があったが 1 日後に枯渴したため, 溜り水と判定 され，止水注入は行なっていない。

(2) 異常出水状況

昭和 48 年 12 月 15 日に $3509.60 \mathrm{~m}$ に到達後, 正月休 みをはさんで縫い返し（3498.75 m から馬蹄形から円形 支保工に変更) を行なっていた時に出水している。

昭和 49 年 1 月 8 日に $3509.60 \mathrm{~m}$ 切羽より, $1.40 \mathrm{~m}$ 後方の天盤の厚さ $20 \mathrm{~cm}$ の吹付けコンクリートをピッ ク掘りしていたところ，5時 30 分頃土砂を伴った 360 $l / \mathrm{min}$ の湧水が間歇的に流出してきた。(これ以前には切 羽付近には湧水がほとんど無かった）約 1 日間この水量 が前後する脈動状態が続いた後, 最高約 $12 \mathrm{~m}^{3} / \mathrm{min}$ に達 し，3 日後には $200 \mathrm{l} / \mathrm{min}$ に減少した。な拈，水質は海 水に極めて近いものであることが化学分析の結果判明し $\star^{2)}$ 。〔水没区間長 $800 \mathrm{~m}$, 土砂埋没区間長 $60 \mathrm{~m}$ (約 $\left.\left.1,100 \mathrm{~m}^{3}\right)\right]$

\section{(3) 復旧工事の概要と掘削後の観察}

まず，流出土砂の法尻である $3445 \mathrm{~m}$ にバルクヘッド を構築し，その後方側壁からコアボーリングを 3 孔（1 孔平均 $70 \mathrm{~m}$ ) 実施して破砕帯を調査した。斜め左に向 ほて行なった No. 3 孔の $43.5 \mathrm{~m}$ 付近で $360 \mathrm{l} / \mathrm{min}$ の 湧水 (湧水圧力 $19 \mathrm{kgf} / \mathrm{cm}^{2}$ ) があり, 同時に灰白色の多 孔質な浮石質凝灰岩（流出土砂にも多量に混入している もの）の存在を確認した。その後, $3460.50 \mathrm{~m}$ の位置に バルクヘッドを構築し，その手前に埋没していた機械を
撤去し，流出土砂部分缼よび周辺地盤部分に注入を行な ってから土砂を取り除いて前進して $3484.90 \mathrm{~m}$ にバル クヘッドを構築した。続いて $3450 \mathrm{~m}$ 付近右側の注入用 ピットから 2 本のコアボーリング (No. 4 孔は $54 \mathrm{~m}$, No. 5 孔は $75 \mathrm{~m}$ ) を行なって崩壊地点の $3509.60 \mathrm{~m}$ 付 近を探査し，断層破砕帯和よびその上部の硬質な熔結凝 死岩と,さらに上部の軟質な粗粒凝灰岩の存在を確認し た。ここで再び流出土砂並びに周辺地盤に対して注入を 行らため, $3450 \mathrm{~m}$ 付近の安定した安山岩質凝灰岩の分 布域に（坑道の左右に）注入横坑を掘削して注入を行な い, $3507.15 \mathrm{~m}$ まで前進して再びバルクヘッドを構築し た。この前進に併行して右側の注入横坑から二重管リバ ース工法を採用して先進ボーリングを行なった。このボ ーリングで $35 \mathrm{~m}$ から破碎粘土に遭遇し， $48 \mathrm{~m}$ から多 孔質凝灰岩， $71 \mathrm{~m}$ から玄武岩に变り，1000 l/min の湧 水があった。さらに $87 \mathrm{~m}$ 付近から砂質凝灰岩になって $1200 \mathrm{l} / \mathrm{min}$ の湧水と共に $4 \mathrm{~m}^{3}$ の土砂が流出した。 $89 \mathrm{~m}$ 以降は局部的にコアは破砕され, 涌水も多かったが安定 した凝灰角碩岩であった。このボーリングの結果，坑道 では破砕帯が $3530 \mathrm{~m}$ 付近まで続き，3545 $\mathrm{m}$ に玄武岩 岩脈があり，多孔質の凝灰岩を挟んで多量の地下水を泼 胎していることが判明した。

その後, $3507.15 \mathrm{~m}$ から地盤注入を行なった後, $3519.20 \mathrm{~m}$ まで掘削して再びバルクヘッドを構築した。 支保工は肉厚 $8.2 \mathrm{~mm}$ の 8 インチ鋼管を用い, 建込後, モルタルを鋼管の中に注入している。工法はショートべ ンチ工法を採用した。

崩壊部分の $3507.15 \mathrm{~m} \sim 3509.60 \mathrm{~m}$ 間は多孔質の凝灰 岩が流出したもので，この間の支保工 3 基はアーチの肩 付近で切断され，天盤からの岩塊でねじり倒されてい た。

$3519.20 \mathrm{~m}$ から地盤注入後, 破砕帯を続けて掘削した が， $3524.20 \mathrm{~m}$ から切羽の肌落ちが目立ち，上半の掘削 面にレジンアンカーを打設した。(異形棒鋼 $\phi 22 \mathrm{~mm}$, $l=5 \mathrm{~m}) 3529.70 \mathrm{~m}$ から多孔質の凝灰岩が現われ，浸出 水があり, 剝落が多くなったため $3530.70 \mathrm{~m}$ で掘削を 止め, バルクヘッドを構築した。これにより出水断層を 突破したが，破砕帯は，主として，破砕による粘土，粘 土化したソープストーン様の岩石からなり，一部に硬質 な礫を主とした断層角碩が認められた ${ }^{2), 7) 。 ~}$

(4) 流出土砂について

流出して坑道を埋めた土砂の礫の種類は, 多い方から 順に下記の通りであり，礫径は $2 \mathrm{~mm}$ から $60 \sim 70 \mathrm{~cm}$ 角まで雑多である。

(1) 赤褐色, 緑色等の多様の色を示す粘土化した細粒 
凝灰岩（ソープストーン様）

(2) 多孔質, 珪質の石英安山岩, 石英安山岩質凝死岩

(3) 細円磷を散含あるいは層状に含む細粒凝灰岩, 他

飞, 緑色斑点を持つ泥質凝灰岩, 安山岩質凝灰岩

上記の (1) は安山岩質凝灰岩の背後に，末た (2) の石 英安山岩質凝灰岩は (1) の背後に分布していることが今 までのボーリング等の調査で明らかになった。このこと から, 流出土砂の供給源は, 主として出水地点の直上部 であり，側方からの移動はほとんど無かったものと考光 られる7。

(5) 異常出水の原因について

(1) 断層破砝帯は角磁状の部分があり, 従って透水性 が高く地下水貯留能力があった。

(2) 断層の両側は亀裂に沿ってかなりの地下水を胚胎 しうる福山層からなっていた。

(3) 破砕带部分はピックで容易に掘れる程度で, せ九 断強度が小さい。

以上の環境条件から掘削後, 坑道の周壁预よび切羽を コンクリート吹付けにより保護したことにより, 坑道背 面に浸出水が蓄積され, その水圧が破砕帯のせん断強度 を越えたために異常出水となったものと考觉られ, 流出 後急激に減水した理由としては急激な大量の流出によ り，水路に目詰りを生じたためと考えられる7。

2.2 .4 竜飛作業坑 $3689.90 \mathrm{~m}$ (本坑換算 $16 \mathrm{k} 890.00$ $\mathrm{m})$ 付近 (水深 $78 \mathrm{~m}$, 土被り $102 \mathrm{~m}$ ) 出水断層

（1）地質および掘削前の調查の概要（図-4 参照）

Kn 1 の凝扊岩の中に玄武岩岩脈が貫入している地帯 で, 断層破砕帯 (影響帯) の中で出水事故が起きてい る。

吉岡の F. 10 付近と同様に崩壊しやすい变質した凝灰 岩と玄武岩のためにワイヤライン式の先進ボーリングが 難航し, 右側の $16 \mathrm{k} 415.50 \mathrm{~m}$ からの TSB-7 号孔が $276 \mathrm{~m}$ で掘進不能となって和り, 左側 1 本 (TSB-8 号 孔）乙か実施して括らず，乙かも湧水源となった玄武岩 の岩脈は, その幅の変化が激しいためボーリングでは探 知されていない。従って先進ボーリングでの湧水も少な かった。このため, 切羽からのコアボーリング, さぐり さっ孔によって涌水並びに破䂗帯を探知し, 止水注入後 掘削しているが，掘削中に湧水並びに変状を認め，増枠 を施工して掘削続行中に異常出水となった。〔上記破碎 帯に対する 2 回の切羽止水注入 ( $16 \mathrm{k} 830.90 \mathrm{~m}$ 㧊よび $16 \mathrm{k} 864.80 \mathrm{~m}$ から）では最高涌水圧力 $18 \mathrm{kgf} / \mathrm{cm}^{2}, 1$ 孔当り最大涌水量 $1600 \mathrm{l} / \mathrm{min}$, 注入孔数 41 孔, 注入量 $\left.528 \mathrm{~m}^{3}\right]^{7)}$

掘削は $16 \mathrm{k} 869.60 \mathrm{~m}$ から $9 \mathrm{~m}$ 間は粘土化した破碎
帯を含む岩質となったので円型断面で $150 \mathrm{H}$ 型支保工間 隔 $0.9 \mathrm{~m}$, 吹付けコンクリート (20 cm 厚) 併用のショ ートベンチ工法とし， $16 \mathrm{k} 878.60 \mathrm{~m}$ より $10 \mathrm{~m}$ 間は地 質がや子好転したので，インバート付き $150 \mathrm{H}$ 型支保工 間隔 $1.0 \mathrm{~m}$ とし，ピック掘り，一部発破工法で掘削直 後, 吹付けコンクリート $(20 \mathrm{~cm}$ 厚) を施工した。この $10 \mathrm{~m}$ 間で支保工に变状が認められたので切羽側 $5 \mathrm{~m}$ 間 に増枠を 5 基施工した。その後支保エピッチを $0.7 \mathrm{~m}$ に変更し, 縫地によりピック掘りで $1.4 \mathrm{~m}$ 掘削し $16 \mathrm{k}$ $890.00 \mathrm{~m}$ に達した。この時点で右側踏前より約 $20 \mathrm{l} / \mathrm{min}$ の湧水があった。

(2) 出水状況

昭和 49 年 12 月 5 日 19 時, 作業坑 $16 \mathrm{k} 890.00 \mathrm{~m}$ で 支保工の建込みを終了し，吹付けコンクリートを右手側 より施工開始した。吹付け中，切羽の右側踏前付近にあ る残涌水約 $20 l / \mathrm{min}$ が $30 \sim 50 l / \mathrm{min}$ に脈動的に増加し た。 3.5 時間後に, $6 \mathrm{~m}^{3} / \mathrm{min}$ に増加し, 以後約 5 日間最 高 $10 \mathrm{~m}^{3} / \mathrm{min}$ 飞達する脈動をくり返した後, $3.6 \mathrm{~m}^{3} / \mathrm{min}$ に減少した。水質は塩分濃度が海水の約 $70 \%$ とやや低 いが，海水が地山を浸透してくる過程でイオン交換を行 なって変質したものと考兄られる 土砂埋没区間 $70 \mathrm{~m}\left(\right.$ 土砂量 $\left.1,300 \mathrm{~m}^{3}\right)$ ]

(3) 万回坑による断層突破までの経過概要

TSB-8 の結果より左側（西側）に玄武岩の貫入の少な い地帯があることが推定されたこともあり, 先進ボーリ ング TSB-8B による追加調查の後, $16 \mathrm{k} 765 \mathrm{~m}$ より左 側に分岐して進むことになった。その後分岐した新作業 坑の掘進に併行して, 旧作業坑の分岐点付近および, 新 作業坑の $16 \mathrm{k} 850 \mathrm{~m}$ 付近の注入横坑から 7 本のコアボ ーリングを行なって断層破砕带を調查した後, 注入横坑 から出水部分に対して止水注入が実施された

調査ボーリングの結果, $16 \mathrm{k} 800 \mathrm{~m} \sim 16 \mathrm{k} 900 \mathrm{~m}$ の付 近では，岩脈を伴う破砕帯の幅は $20 \sim 25 \mathrm{~m}$ で東側限 （上盤との境界）は比較的明瞭に境されており，上盤の 地質は砂質凝灰岩, 泥岩 (Kn 2 に相当する) などであ ることが判明すると共に, 断層の一般走向は N10 15 $\mathrm{W}$ と推定された。さらに $16 \mathrm{k} 900 \mathrm{~m} \sim 17 \mathrm{k} 100 \mathrm{~m}$ 間に ついては, 切羽からボーリング 2 本が実施された結果, 断層はうねりながら次第に作業坑に近づく傾向を認めた ので, $17 \mathrm{k} 100 \mathrm{~m}$ 地点から, 作業坑はさらに $20^{\circ}$ 西方 へ向って掘進し, $17 \mathrm{k} 200 \mathrm{~m}$ 付近から断層の走向とほら゙ 一致する方向で直進することになった。その後も切羽ボ ーリングや TSB-11, TSB-12 拈よび TSB-11 の先進ボ ーリングによって破碎帯が坑道にほよ゙平行していること を確認しながら進行している。 
地質は $17 \mathrm{k} 450 \mathrm{~m}$ 付近から（石英安山岩質）凝灰岩 より上位の砂質凝灰岩，泥岩等の堆積岩類が優勢とな り，岩盤状態は安定し， $17 \mathrm{k} 600 \mathrm{~m}$ 付近まで掘進は順調 に進んだ。

この間に行われた先進ボーリング TSB-12，TSB-11 によって前者は 522 530 m，後者は 213〜223 m 間で， それぞれ破砕帯とこれに伴ら涌水（それぞれ $1600 l / \mathrm{min}$ と $3000 \mathrm{l} / \mathrm{min}$ でいずれも水質は海水に極めて近いもの) が認められた。

この破砕帯がその後実施された TSB-11 横坑からの 追加ボーリングによって出水断層の延長に相当するもの と判定され，掘削の結果 $17 \mathrm{k} 673 \mathrm{~m}$ 在側壁から $17 \mathrm{k}$ $687 \mathrm{~m}$ 左側壁に抜ける断層として認められた。破砕幅は 20 25 m で，地質は凝灰岩を取り达むが上下盤共に褐 色泥岩である。その走向傾斜は $\mathrm{N} 25^{\circ} \mathrm{W} 80^{\circ} \mathrm{NE}$ であり, 上盤側派生の断層面として $17 \mathrm{k} 691.4 \mathrm{~m}$ 右側壁で $\mathrm{N} 30$ $\sim 43^{\circ} \mathrm{W} 80^{\circ} \mathrm{NE}, 17 \mathrm{k} 696.7 \mathrm{~m}$ 右側壁で $\mathrm{N} 42^{\circ} \sim 52^{\circ} \mathrm{W}$ $72^{\circ} \sim 80^{\circ} \mathrm{NE}$ が認められ，この間が破砕帯を形成してい る。この破砕帯の掘削は止水注入後, $150 \mathrm{H}$ 型円形支保 工を $0.7 \mathrm{~m}$ 間隔で建込むピックおよび自由断面掘削機 (アルピネマイナー) 併用によるショートベンチ工法に よって行われた。 $17 \mathrm{k} 700 \mathrm{~m}$ 以降の出水断層は左手に抜 けたが，この追跡については $18 \mathrm{k} 200 \mathrm{~m}$ 地点で TSB14B ボーリングによって坑道から約 $170 \mathrm{~m}$ 離れた位置 で確認した。したがって $17 \mathrm{k} 700 \mathrm{~m} \sim 18 \mathrm{k} 200 \mathrm{~m}$ 間では 走向 $\mathrm{N} 25^{\circ} \mathrm{W}$ 前後であることが確認された 砕帯に対する 2 回の切羽止水注入 (17 k $642.60 \mathrm{~m}$ 抢よ
び $17 \mathrm{k} 671.50 \mathrm{~m}$ から）では最高涌水圧力 $19 \mathrm{kgf} / \mathrm{cm}^{2}$, 1 孔当り最大湧水量 $1300 \mathrm{l} / \mathrm{min}$, 注入孔数 108 , 注入量 $1017 \mathrm{~m}^{3}$ ]

なお，その後この断層は，本坑等でその延長部分をそ れぞれ入念な止水注入によって無事突破しているが，そ の概要は表-1の通りである??。

（4）異常出水の原因について

玄武岩岩脈が水道となっており，掘削に伴ら緩みによ り亀裂（グラウトで一時充埧されていた部分を含む）が 開口し，不透水層の凝灰岩層背後の間隙水圧の上昇によ って脆弱な破砕部分が破壊されたため土砂流出を伴う異 常出水となったものと考光られる。

2.2 .5 吉岡作業坑 $4588.50 \mathrm{~m}$ (本坑換算 $31 \mathrm{k} 667.95$ $\mathrm{m}$ ) 付近（水深 $76 \mathrm{~m}$ ，土被り $128 \mathrm{~m}$ ) の 5.6 (出水) 断層

(1) 地質および掘削前の調査の概要（図-5 参照）

Kn 1 の砂質凝灰岩 (一軸圧縮強度 $100 \mathrm{kgf} / \mathrm{cm}^{2}$ 前後), 火山碰凝灰岩 (同 $140 \mathrm{kgf} / \mathrm{cm}^{2}$ ) の分布域の断層であり, $4536.30 \mathrm{~m}$ からの第 20 回注入， $4557.80 \mathrm{~m}$ からの第 21 回注入を実施後, 掘削して出水切羽に到達している。第 20 回注入では, $4615 \mathrm{~m}$ までを注入しているが，切羽か ら $40 \mathrm{~m}$ 付近で $200 \sim 400 \mathrm{l} / \mathrm{min}$ の湧水があり，また上 向きのせん孔では 40〜 $44 \mathrm{~m}$ 付近でジャミングをしてい るので, 断層破砕帯の可能性のあることが考光られてい るが，坑道の左側を進んでいる SB-10 先進ボーリング でも断層を探知していないこともあり，特に不安定な岩 盤とは判定されなかった。

表-1 竜飛出水断層の坑道別地質状況之掘削工法

\begin{tabular}{|c|c|c|c|c|}
\hline 坑 道 名 & 破砕帯区間長 & 上盤の地質 & 下盤の地質 & 掘 削工 法 \\
\hline $\begin{array}{c}\text { 作 業 坑 } \\
(17 \mathrm{k} 690 \mathrm{~m} \text { 付近 })\end{array}$ & $25 \mathrm{~m}$ & 褐色泥岩 & 褐色泥岩 & $\begin{array}{l}\text { 円形ショートベンチ工法（ピッ } \\
\text { ク及び自由断面掘削機） } \\
\text { 150H リング支保工 }\end{array}$ \\
\hline $\begin{array}{l}\text { 第 } 5 \text { 連 絡 坑 } \\
(17 \mathrm{k} 020 \mathrm{~m} \text { 付近 })\end{array}$ & $26 \mathrm{~m}$ & 硬質褐色泥岩 & $\begin{array}{l}\text { 粘土化著しい軽 } \\
\text { 石質石英安山岩 } \\
\text { 質凝在岩 }\end{array}$ & $\begin{array}{l}\text { 円形ショートベンチ工法 } \\
150 \mathrm{H}, 200 \mathrm{H} \text { リング支保工 }\end{array}$ \\
\hline $\begin{array}{l}\text { 先 進 導 坑 } \\
(17 \mathrm{k} 690 \mathrm{~m} \text { 付近 })\end{array}$ & $60 \mathrm{~m}$ & 硬質褐色泥岩 & 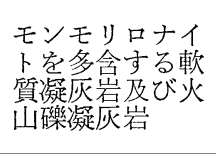 & $\begin{array}{l}\text { 全断面掘削工法（ピック及び小 } \\
\text { 発破） } \\
200 \mathrm{H} \text { 馬蹄形支保工（インバー } \\
\text { トストラット付） }\end{array}$ \\
\hline $\begin{array}{l}\text { 第 } 4 \text { 本 坑 } \\
(16 \mathrm{k} 800 \mathrm{~m} \text { 付近 })\end{array}$ & $60 \mathrm{~m}$ & $\begin{array}{l}\text { 凝灰質砂岩及び } \\
\text { 褐色泥岩 }\end{array}$ & $\begin{array}{l}\text { 小割目の発達し } \\
\text { た軟質凝有岩 }\end{array}$ & $\begin{array}{l}\text { サイロットエ法 } \\
250 \mathrm{H} \text { コンクリート巻厚 } 1.0 \mathrm{~m}\end{array}$ \\
\hline
\end{tabular}


その後実施された右側の SB-11 先進ボーリングは, 出水切羽付近では坑道右側壁から $10 \mathrm{~m}$ 離れて, 高さは 天盤の上方 $19 \mathrm{~m}$ の位置にあるが，深度 $202 \mathrm{~m}$ (作業坑 桲程で $4566 \mathrm{~m}$ 地点) で $4000 \mathrm{l} / \mathrm{min}$ の涌水と共に $3 \sim 4$ $\mathrm{m}^{3}$ の土砂流出があった。このため, $4557.80 \mathrm{~m}$ で切羽 を止め，補助注入として第 21 回注入を行なったが，9 孔で総涌水量が $69 \mathrm{l} / \mathrm{min}$ と湧水は少なく, $92 \mathrm{~m}^{3}$ を注入 して掘削が続けられた。（第 20 回注入では，注入孔数は 29 孔, 注入量 $290 \mathrm{~m}^{3}$ )

掘削中, $4576 \mathrm{~m}$ 付近から亀裂叔よび涌水が多くなり, $4584.30 \mathrm{~m}$ から支保工間隔を $1.0 \mathrm{~m}$ から $0.7 \mathrm{~m}$ に縮め, 縫い地で上部半断面を鏡止めしながら全断面をピック掘 りで進めたが出水切羽付近の天盤や側壁から数 $10 \mathrm{l} / \mathrm{min}$ の涌水があっだ?。

(2) 出水状況

昭和 51 年 5 月 6 日, 2 時 25 分, $4588.50 \mathrm{~m}$ の切羽鏡 止め作業中，天端より $15 \mathrm{l} / \mathrm{min}$ の湧水があり，(4 m 手 前の) $4584 \mathrm{~m}$ 付近の湧水 (30 l/min 程度) が止った。 1 時間後に $4 \mathrm{~m}^{3} / \mathrm{min}$, さらに 11 時間後に最高の $85 \mathrm{~m}^{3} /$ $\min$ に達し, 3 日後約 $20 \mathrm{~m}^{3} / \mathrm{min}$, 以後少しらつ減少し ながら，2箇月後 $16 \mathrm{~m}^{3} / \mathrm{min}$ まで減少。な执，水質は海 水に極めて近いものと判定された ${ }^{5)}$ 。【水没区間長，作業 坑 $3015 \mathrm{~m}$, 本坑 $1395 \mathrm{~m}$, 土砂埋没区間 $74 \mathrm{~m}$ (約 1000 $\left.\left.\mathrm{m}^{3} / \mathrm{min}\right)\right]$

（3）迂回坑による断層突破までの経過概要

作業坑 $1573 \mathrm{~m}$ および本坑 $34 \mathrm{k} 604 \mathrm{~m}$ 付近にバルク ヘッドを構築した後, 強制排水を行なって, 流出土砂の 法尻の $4515 \mathrm{~m}$ に再びバルクヘッドを構築した。その 後, ルート変更が検討され，出水切羽から $139 \mathrm{~m}$ 後方 の $4449.30 \mathrm{~m}$ より西側へ迁回坑を掘削することとし， 迂回坑の進行方向に 3 孔（1 孔につき $100 \mathrm{~m}$ 前後）の 調査ボーリングを行ない，また先進導坑からも作業坑へ 向けて破砕帯調查のため 5 孔（1 孔につき $100 \mathrm{~m}$ 前後） の調査ボーリングを行なった後, 止水注入しながら掘削 して断層を突破している5 。〔破䂶帯に対する注入とし ては $4609.28 \mathrm{~m}$ からの第 22 回注入と $4639.38 \mathrm{~m}$ から 第 23 回注入があり，1 孔最大湧水量は，200 l/min，最 大涌水圧力 $20 \mathrm{kgf} / \mathrm{cm}^{2}$, 合計注入孔数 165 孔, 注入量 $1726 \mathrm{~m}^{3}$ ]

作業坑は $4662 \mathrm{~m}$ から断層破砕帯に入り, 断層の走 向傾斜は $\mathrm{N} 10^{\circ} \mathrm{E} 60^{\circ} \mathrm{SE}$, 地質は火山硆凝灰岩で, 岩片 を手で容易に崩せる程，軟弱化して拈り，4664 m, 4669 $\mathrm{m}, 4674 \mathrm{~m}$ の 3 箇所に厚い粘土層（最大 $40 \mathrm{~cm}$ ) が確認 され, 肌落ち等が顕著になり不安定な状態となった。断 層破砕帯は $4690 \mathrm{~m}$ までの $28 \mathrm{~m}$ 間であり, 断層上盤の
境界は，粘土帯を伴わず漸移的に良好な地山に移行して いる。掘削工法は，4661.77〜 4718.48 m までショート ベンチ工法 (発破工法) で， $150 \mathrm{H}$ 円型支保工を $0.7 \mathrm{~m}$ 間隔で建込んでいる。なお，この断層は，出水月日にち なんで, 5.6 断層と名付けられた。

その後サイロット工法で掘削した本坑での破砕帯は， 東側導坑で $31 \mathrm{k} 711 \mathrm{~m} \sim 31 \mathrm{k} 700 \mathrm{~m}$ (11 m 間), 西側導 坑で $31 \mathrm{k} 706 \mathrm{~m} \sim 31 \mathrm{k} 701 \mathrm{~m}$ (5 m 間) に出現し，下盤 側の境界が明瞭な厚さ $5 \mathrm{~cm}$ 以内の褐色粘土を伴う逆断 層 (走向傾斜 $\mathrm{N} 30^{\circ} \mathrm{E} 40^{\circ} \mathrm{SE}$ ) で垂直落差は約 $30 \mathrm{~m}$ 。 作業坑のように厚い粘土は認められないが，粘土化して 軟化した火山碩凝灰岩の中に，すべり面の顕著な小断層 や亀裂が集中的に発生している。

な和先進導坑では破砕帯が認められず, $31 \mathrm{k} 610 \mathrm{~m}$ 付 近（先進導坑距離程 $4110 \mathrm{~m}$ ) の断層が 5.6 断層の延長 部分と判定された7)。SB-10 ボーリングでも破砕帯が認 められなかったこともあり, 破砕幅の変化の激しい断層 と推定される。

（4）異常出水の原因について

断層破砕帯付近に水道があり，掘削に伴ら緩みにより 亀裂（グラウトで一時充填されていた部分を含む）が開 口し，水坧により破砕帯中の脆弱な部分が破壊されたた め, 土砂流出を伴ら異常出水となったものと考えられ る。

\section{3 今後の課題}

異常出水箇所の地質の共通点は, 涌水源となっている 透水性の地質と掘削後緩みの生じやすい破砕帯等の軟弱 な地質が共存していることであり，事前の徴候としては ボーリングやさぐりさっ孔等でジャミングや多量の湧水 が認められていること，また，直前の掘削中に湧水や変 状が認められていることが上げられる。

異常出水防止のためには, 坑道周辺の滞水状況, 緩み 状況を把握することが必要であり，これは非常に難しい 問題であるがボーリング孔の利用等による各種測定以外 にはないと思われ，今後のトンネルの保守管理のために も重要な研究課題と考える。

\section{3. 涌水の水質}

青函トンネルでは, 先進ボーリングや坑道掘削時の涌 水が海水の直接浸透水かどらかを現場で迅速に判定する ため鉄道技術研究所化学研究室に研究並びに分析技術指 導を委託し，現地試験室（鉄道公団直轄）に適合した水 質簡易分析法が確立された。

現地での分析は, 先進ボーリング, 切羽注入時の穿孔 および坑道掘削後の切羽，側壁等の涌水を採取して行な 
表-2 異常出水に批け

\begin{tabular}{|c|c|c|c|c|c|c|c|c|}
\hline \multirow{2}{*}{$\begin{array}{l}\text { 異常出水 } \\
\text { 年 月 }\end{array}$} & \multirow{2}{*}{$\begin{array}{c}\text { 出 水 箅 所 } \\
\text { (本坑換算籸程) }\end{array}$} & \multirow{2}{*}{$\begin{array}{c}\text { 水 深 } \\
\mathrm{m}\end{array}$} & \multirow{2}{*}{$\begin{array}{c}\text { 土被り } \\
\mathrm{m}\end{array}$} & \multirow{2}{*}{$\begin{array}{l}\text { 最, 大 } \\
\text { 湧水量 } \\
\mathrm{m}^{3} / \mathrm{min}\end{array}$} & \multirow{2}{*}{$\begin{array}{l}\text { 水 温 } \\
{ }^{\circ} \mathrm{C}\end{array}$} & \multirow{2}{*}{$\mathrm{pH}$} & \multicolumn{2}{|c|}{ 化 学 } \\
\hline & & & & & & & $\mathrm{Na}^{+}$ & $\mathrm{K}^{+}$ \\
\hline $\mathrm{S} 44.2 .14$ & $\begin{array}{c}\text { 竜飛調查斜坑 } \\
1222.80 \mathrm{~m}\end{array}$ & 25 & 215 & 11 & - & 8.5 & 405 & 7.0 \\
\hline $\mathrm{S} 49.1 .8$ & $\begin{array}{c}\text { 吉 岡作 業 坑 } \\
3509.60 \mathrm{~m} \\
(32 \mathrm{k} 746.85 \mathrm{~m})\end{array}$ & 58 & 134 & 12 & 19 & 8.4 & 435 & 6.4 \\
\hline S 49.12 .5 & $\begin{array}{c}\text { 竜飛作業坑 } \\
3689.90 \mathrm{~m} \\
(16 \mathrm{k} 890.00 \mathrm{~m})\end{array}$ & 78 & 102 & 10 & 19 & 7.6 & 309 & 6.1 \\
\hline S51. 5.6 & $\begin{array}{c}\text { 吉宬作業坑 } \\
4588.50 \mathrm{~m} \\
(31 \mathrm{k} 667.95 \mathrm{~m})\end{array}$ & 76 & 128 & 85 & 17 & 8.0 & 405 & 10.3 \\
\hline
\end{tabular}
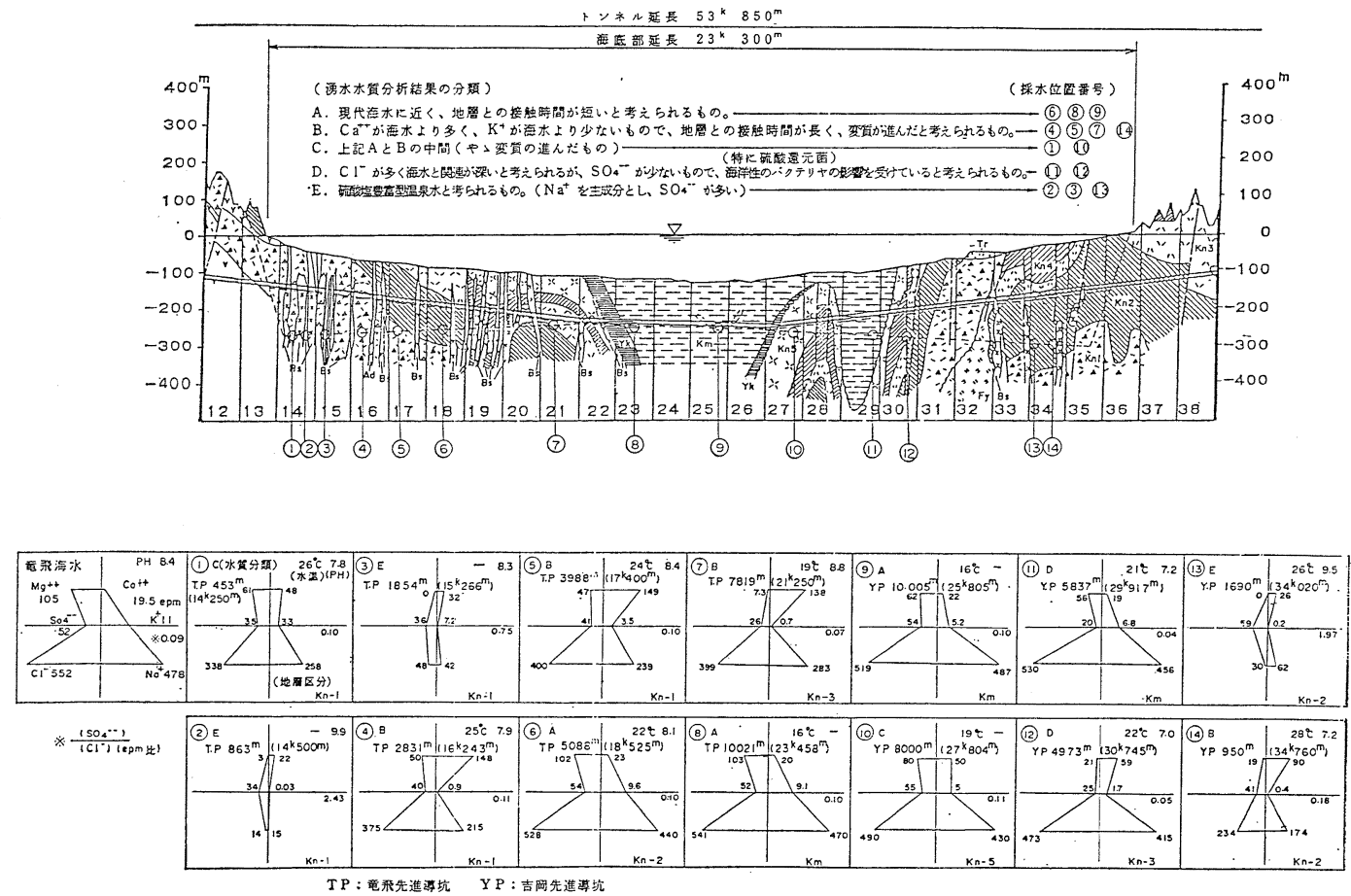

図-6 青函トンネル先進導坑，湧水水質分析一覧図（へキサダイヤグラム）

っており，主な分析項目と方法は，

$\mathrm{PH}$ はガラス電極法, アルカリ度は中和滴定法, $\mathrm{Na}$, $\mathrm{K}$ イオンは炎光分析法または原子吸光分析法, $\mathrm{Ca}, \mathrm{Mg}$ イオンは EDTA 滴定法または原子吸光分析法, $\mathrm{Cl}$ 个 オンは硝酸銀滴定法, $\mathrm{SO}_{4}$ イオンは硫酸バリウム比濁法
で行なっている9)。

海底部の涌水は海水に近いものが大半を占めるが，浸 透の過程でイオン交換等によって変質海水型になってい るものが多く, 部分的には温泉水型のものが認められ $ろ^{8)}$ 。 
る水質分析結果一覧表

\begin{tabular}{|c|c|c|c|c|c|c|}
\hline 分 & 析 位 & (ep & & $\mathrm{SO}_{4}^{--} / \mathrm{Cl}^{-}$ & 折公頪 & 事 \\
\hline $\mathrm{Ca}^{++}$ & $\mathrm{Mg}^{++}$ & $\mathrm{Cl}^{-}$ & $\mathrm{SO}_{4}^{--}$ & (epm 比) & & \\
\hline 40 & 109 & 501 & 41 & 0.08 & $\mathrm{C}$ & \\
\hline 50 & 87 & 522 & 49 & 0.09 & $\mathrm{C}$ & \\
\hline 41 & 72 & 387 & 41 & 0.11 & $\mathrm{C}$ & \\
\hline 36 & 137 & 532 & 58 & 0.11 & A & $\begin{array}{l}\text { 湧水の水温は, S51.5.14 以降 } \\
14^{\circ} \mathrm{C} \text { ま芐っている。 }\end{array}$ \\
\hline
\end{tabular}

先進導坑での代表的な水質のパターンを図-6に示す。 な和, 前述の 4 回の異常出水の水質分析結果を表-2 に示す。

\section{参考 文 献}

1）北原正一 (1970)：渓水後の青函トンネル，施工技術，33.

2) 北村 章 ·鶴田博昭 - 佐々木幹夫 $(1975,1976)$ ：青函卜 ンネル作業坑の破砕帯の施工 (1), (2), 土木施工, 16 巻 15 号, 17 巻 1 号.

3）佐賀政家 - 長野利幸 (1976)：海底下の膨圧 $200 \mathrm{t} / \mathrm{m}^{2}$ に 挑む新技術〈青函トンネル吉岡工区本坑〉，鉄道土木，181.

4）鈴木和也（1975）：青函トンネルの施工 (7), 海底出水と 復旧工事, トンネルと地下, 第 6 巻 12 号.
5）鶴田博昭・ 川下正行・佐々木幹夫（1976）：青函トンネル 作業坑（吉岡方）の異常出水, トンネルと地下, 第 7 巻 10 号.

6) 日本鉄道建設公団青函建設局（青函トンネル物理探査研究 委員会) $(1974,1975,1976)$ ：北海道方海底部坑内物理探 査報告書.

7） 日本鉄道建設公団青函建設局（1972～1977）：海底部坑内 地質調査報告畫, その 1 〜 その 16.

8）青山芳夫・立松英信・阿部 弘・松村宮吉 (1979)：青函 トンネル坑内水の地球化学的研究, 鉄道技術研究報告, No. 1107.

9）滝永 進 (1984)：国鉄における水質調査法一計画とデ 一夕解析の基礎的指針一, 鉄道技術研究所速報, No. A84-112.

10）松下芳亮・前田憲一 (1983)：水平長尺先進ボーリング, 鉄道土木, Vol. 25, No. 3.

(昭和 63 年 2 月 13 日受付, 昭和 63 年 4 月 22 日受理) 